\title{
Trypanocidals Effectivity against Some Isolates of Trypanosoma evansi Propagated in Mice
}

\author{
Subekti DT ${ }^{1}$, Yuniarto $\mathrm{I}^{2}$, Sulinawati ${ }^{3}$, Susiani $\mathrm{H}^{4}$, Amaliah $\mathrm{F}^{5}$, Santosa $\mathrm{B}^{6}$ \\ ${ }^{1}$ Indonesian Research Center for Veterinary Sciences, Bogor, ${ }^{2}$ Veterinary Center Banjarbaru, ${ }^{3}$ Veterinary Center Lampung, \\ ${ }^{4}$ Laboratory of VeterenaryType B Kupang, ${ }^{5}$ Veterinary CenterMaros, ${ }^{6}$ Veterinary Center Bukittinggi \\ E-mail: subekti@litbang.pertanian.go.id
}

(received 10-08-2015; revised 27-10-2015; accepted 25-11-2015)

\begin{abstract}
ABSTRAK
Subekti DT, Yuniarto I, Sulinawati, Susiani H, Amaliah F, Santosa B. 2015. Efektivitas trypanosidal terhadap beberapa isolat Trypanosoma evansi yang diperbanyak di mencit. Indones J Anim Vet Sci. 20(4): 275-284. DOI: http://dx.doi.org/10.14334/jitv.v20i4.1246

Surra merupakan salah satu penyakit menular pada berbagai jenis hewan yang disebabkan oleh protozoa darah. Surra disebabkan oleh Trypanosoma evansi (T. evansi) dan seringkali berakibat fatal berupa kematian yang tinggi terutama pada kuda, kerbau dan unta. Salah satu pengendalian penyakit Surra dapat dilakukan dengan pengobatan menggunakan trypanosidal yang efektif. Efektifitas trypanosidal untuk Surra harus didasarkan pada hasil uji sensitivitas. Oleh sebab itu perlu diteliti efektivitas berbagai trypanosidal terhadap beberapa isolat $T$. evansi yang berasal dari beberapa daerah kasus maupun wabah Surra di Indonesia agar diketahui kesesuaian dan efikasinya. Metode pengujian dilakukan dengan desain pre test-post test. Mencit DDY diinfeksi dengan beberapa isolat $T$. evansi dari beberapa daerah kasus dan diamati parasitemianya. Setelah parasitemia mencapai puncaknya, maka mencit diobati dengan masing-masing trypanosidal dengan dosis bertingkat. Selanjutnya mencit diamati perubahan parasitemianya selama kurang lebih satu bulan. Hasil penelitian menunjukkan bahwa setiap isolat memiliki kepekaan yang berbeda terhadap trypanosidal sehingga penggunaan trypanosidal cenderung spesifik lokasi. Secara umum, suramin dan melarsomine dihydrochloride merupakan dua trypanosidal yang paling efektif untuk beberapa isolat di Indonesia. Adapun isometamidium chloride tidak direkomendasikan digunakan untuk pengobatan kasus surra di Indonesia.
\end{abstract}

Kata Kunci: Trypanosoma evansi, Trypanosidal, Parasitemia, Surra

\begin{abstract}
Subekti DT, Yuniarto I, Sulinawati, Susiani H, Amaliah F, Santosa B. 2015. Trypanocidals effectivity against some isolates of Trypanosoma evansi propagated in mice. Indones J Anim Vet Sci. 20(4): 275-284. DOI: http://dx.doi.org/10.14334/jitv.v20i4.1246

Surra is one of infectious diseases in various types of animals caused by blood parasites called Trypanosoma evansi. It is fatally occurred, especially in horse, buffalo and camel. Surra may be controlled by effectively trypanocidals treatment based on the results of its sensitivity test. Therefore, it is necessary to study the effectiveness of various trypanocidal against some T.evansi isolates originating from several regions in Indonesia with surra case to determine its suitability and efficacy. The test was carried out by pre-test - post-test. Mice were infected by several T.evansi isolates from various infected areas. Their parasitaemia were observed. After reaching peak of parasitemia, the mice were treated by trypanocidal with different doses. Parasitaemia alteration was observed for one month. Observation results showed that all isolates had different sensitivity to the trypanocidals, so that trypanocidals application tended to specific location. Generally, suramin and melarsomine dihydrochloride were the most effective trypanocidal for some Indonesian isolates. In contrast, isometamidium chloride was not recommended to be used for surra control in Indonesia.
\end{abstract}

Key Words: Trypanosoma evansi, Trypanocidal, Parasitemia, Surra

\section{INTRODUCTION}

Surra is one of infectious diseases in various species of animals caused by blood parasites called Trypanosoma evansi (T. evansi). Surra is transmitted by bloodsucking flies (haematophagous flies). Horse and buffalo are sensitive to surra and often leads to high mortality. This happens in Surra outbreak on the island of Sumba, East Nusa Tenggara province in 2010 until 2012. The outbreak resulted in 1159 horses, 600 buffaloes and cows have died (Dirkeswan 2012). Surra still occur in some parts of Indonesia, such as Kalimantan (Borneo), Banten, Lampung, Aceh, and other territories.

One methods for controlling Surra can be done using trypanocidal. Currently, there were 2 approaches, using extract of some herbs and chemically synthetic of active ingredients. Studies using extract of herbs ingredients have been carried out both in vitro or in vivo. But so far, some herbs extract did not success as anti-T. evansi as reported by Abdelrahman (2011), Aman (2013) and Dorneles et al (2013). On the 
contrary, Nzelibe et al. (2013) tested trypanocidal activity of Azadirachta indica seed extract (NSE) and leaves of Tridax procumbens (TP) which showed a success as trypanocidal without relapse when it was combined. Those extracts were not available commercially, and economically those extractions were impossible to be applied to cow, buffalo, and horse.

Therefore, surra treatment using herbs extract still could not be expected, so that must have to rely on chemically synthetic of active ingredient which have been used for 30 to 90 years (Subekti 2014). Active ingredients that have been used as drugs or trypanocidal are suramin, melarsomine dihydrochloride, diminazene diaceturate, quinapyramine and isomethamidium chloride (Steverding 2010; Melaku \& Birasa 2013). Unfortunately, some trypanosome isolates have been reported to develop resistance to some of these trypanocidals from various countries (Melaku \& Birasa 2013). Therefore for an effective treatment against Surra should be based on a sensitivity test to trypanocidal (Melaku \& Birasa 2013). This is because some trypanosidal may not be appropriate for certain T.evansi isolates. Subekti (2014) states that T.evansi isolates originating from different regions have different sensitivity to trypanocidal. On the other hand, trypanocidal which is currently marketed in Indonesia is isometamidium chloride and diminazene diaceturate. The effectiveness of the two drugs are not known against some T.evansi isolates in Indonesia that is attacking livestock. Information about the differences in the sensitivity of T.evansi isolates of Indonesia against various types of trypanocidal also very limited. Therefore it is important to investigate the effectiveness of various trypanocidal against some T.evansi isolates originating from Indonesia, especially from the region of cases or outbreaks of Surra.

\section{MATERIAL AND METHOD}

\section{Trypanosoma evansi isolate}

T.evansi isolates used in this study were from Sumba Timur, province of East Nusa Tenggara; Serang, province of Banten; Hulu Sungai Utara, province of South Kalimantan; and Pesawaran, province of Lampung. All of isolates were propagated in mice before used for infection and treatment.

\section{Infection of experimental animals, treatment, and parasitema observation}

Female DDY strain mice were acclimated and weighed for body weight (BW) grouping. Mice were divided into 5 groups with 5 mice in each group (Table 1). Each mice were infected by $10^{5}$ trypanosoma intraperistoneally (Sones et al. 1998). Treatment was carried out when the infected mice have reached $4+$ of parasitemia or equivalent to $10^{8}-10^{9}$ trypanosoma $/ \mathrm{mL}$ of blood.

Treatment was carried out intraperitoneally using each drugs or trypanocidal and dose applied individually according to mice body weight (Table 1) as described by FAO (Uilenberg 1998). Drug used consisted of melarsomine dihydrochloride, suramin, diminazene diaceturate and isometamidium chloride. Parasitemia observation was carried out every day for one week post-treatment and continuing every two days in the subsequent observation period up to one month.

Table 1. Experimental design of some trypanocidals against different T.evansi isolates

\begin{tabular}{|c|c|c|c|c|c|c|c|c|}
\hline \multirow[t]{2}{*}{ Isolate } & \multicolumn{2}{|c|}{$\begin{array}{c}\text { Melarsomine } \\
\text { dihydrochloride } \\
(\mathrm{mg} / \mathrm{kg} \mathrm{BB})\end{array}$} & \multicolumn{2}{|c|}{$\begin{array}{c}\text { Suramin } \\
\text { (mg/kg BB) }\end{array}$} & \multicolumn{2}{|c|}{$\begin{array}{l}\text { Diminazene } \\
\text { diaceturate } \\
(\mathrm{mg} / \mathrm{kg} \mathrm{BB})\end{array}$} & \multicolumn{2}{|c|}{$\begin{array}{c}\text { Isometamidium chloride } \\
(\mathrm{mg} / \mathrm{kg} \mathrm{BB})\end{array}$} \\
\hline & 0.25 & 0.75 & 5 & 10 & 3.5 & 7 & 0.5 & 1 \\
\hline 372 & 5 & 5 & 5 & 5 & 5 & 5 & 5 & 5 \\
\hline 373 & 5 & 5 & 5 & 5 & 5 & 5 & 5 & 5 \\
\hline S13 & 5 & 5 & 5 & 5 & 5 & 5 & 5 & 5 \\
\hline S18 & 5 & 5 & 5 & 5 & 5 & 5 & 5 & 5 \\
\hline A14 & 5 & 5 & 5 & 5 & 5 & 5 & 5 & 5 \\
\hline PLS & 5 & 5 & 5 & 5 & 5 & 5 & 5 & 5 \\
\hline
\end{tabular}

$372=$ T.evansi isolate from Sumba Timur, province of East Nusa Tenggara (isolated in 2012)

$373=$ T.evansi isolate from Sumba Timur, province of East Nusa Tenggara (isolated in 2012)

$\mathrm{S} 13=$ T.evansi isolate from Serang, province of Banten (isolated in 2014)

$\mathrm{S} 18=$ T.evansi isolate from Serang, province of Banten (isolated in 2014)

$\mathrm{PLS}=$ T.evansi isolate from Pesawaran, province of Lampung (isolated in 2013)

A14= T.evansi isolate from Hulu Sungai Utara, province of South Kalimantan (isolated in 2014) 
Parasitemia observation was carried out with 3 techniques. First by native observation using a microscope. Negative results on the observation of native then followed by observation using MHCT (Microhaematocrit centrifugation Technique) and BCT (Buffy Coat Technique) as described in the OIE (2012). Mice were declared cured if result of blood test is not found Trypanosome with native examination, MHCT or BCT until the end of the experiment. Otherwise, if the one of those observations was positive, mice were stated sick and parasitemia positive.

\section{RESULT AND DISCUSSION}

\section{Efficacy of several trypanocidals against several T.evansi isolates}

Test result showed that anti-trypanosome drug (trypanocidal) had different efficacy to some isolates of T.evansi from several regions in Indonesia. Treatment with melarsomine dihydrochloride in mice infected with T.evansi isolates 372 and 373 have been declared cured at a dose 0.25 and $0.75 \mathrm{mg} / \mathrm{kg} \mathrm{BW}$ (Figure 1.A). Treatment with melarsomine dihydrochloride at a dose of $0.75 \mathrm{mg} / \mathrm{kg} \mathrm{BW}$, also provides a satisfactory recovery $(100 \%$ cured) of the mice infected with T.evansi isolate S13, S18 and PLS (Figure 1A). These results are similar to previous studies in mice infected with the 371 and 375 isolates originating from Sumba Timur. In mice that have been infected with the isolate 375 , melarsomine dihydrochloride can cure mice at a dose of 0.25 and $0.75 \mathrm{mg} / \mathrm{kg} \mathrm{BW}$ (unpublished data). In contrast, mice that have been infected with the isolate 371 , only cured by melarsomine dihydrochloride at a dose $0.75 \mathrm{mg} / \mathrm{kg} \mathrm{BW}$ (unpublished data). The mice infected with the PLS isolate from Lampung only $80 \%$ is recovered at a dose of $0.25 \mathrm{mg} / \mathrm{kg} \mathrm{BW}$.

Suramin effectively used for most isolates of T.evansi being tested. Suramin at a dose 5 and $10 \mathrm{mg} / \mathrm{kg}$ BW can cure $100 \%$ of mice infected with the isolates 372, 373, S13, PLS and A14. Suramin at a dose 10 $\mathrm{mg} / \mathrm{kg}$ BW cures only $80 \%$ of mice infected with the S18 isolate (Figure 1.B). In mice that had been infected with the isolates 375 and 371 , suramin give $75 \%$ recovery at doses of 5 and $10 \mathrm{mg} / \mathrm{kg} \mathrm{BW}$ (unpublished data).

On the other hand, diminazene diaceturate and isometamidium chloride which are widely marketed in Indonesia did not show satisfactory effectiveness compared with melarsomine dihydrochloride and suramin. Diminazene diaceturate only effective for mice infected with the PLS isolate at doses of 3.5 and 7 $\mathrm{mg} / \mathrm{kg} \mathrm{BW}$. In contrast, mice infected with the 372 and S13 isolates only recovered when treated with diminazene diaceturate at dose of $7 \mathrm{mg} / \mathrm{kg} \mathrm{BW}$ (Figure 1.C). Conversely, all of mice infected by the sixth T.evansi isolates did not cured when treated by isometamidium chloride. Generally, mice still showed high parasitemia after treatment. This fact provides evidence that the six T.evansi isolates being tested are resistant to treatment with isometamidium chloride up to a dose $1 \mathrm{mg} / \mathrm{kg} \mathrm{BW}$.

Resistance to isometamidium chloride has been widely documented. Among them are reports of Macaraeg et al (2013) which states that a cure can be achieved when using isometamidium chloride at a dose $10 \mathrm{mg} / \mathrm{kg} \mathrm{BW}$ in T.evansi isolates from the island of Luzon, and Visayas, Philippines. The dose is 10 times higher than recommended dose as used in this experiment (Subekti 2014). However, Homeida et al. (1980) reported that mice infected with T.evansi coming from the East Sudan at a dose of $10^{5}$ per mice and treated with $10 \mathrm{mg} / \mathrm{kg} \mathrm{BW}$ of isometamidium chloride only partially cured (approximately $40 \%$ recovery). Two mice were cured through observations of more than 30 days, 2 mice showed a relapse (40\%) and 1 mice died $(20 \%)$. These results suggest that the usage isometamidium chloride treatment more than $1 \mathrm{mg} / \mathrm{kg}$ BW also does not guarantee a cure. Jatau et al (2010) reported that treatment with isometamidium chloride at a dose of $0.5 \mathrm{mg} / \mathrm{kg} \mathrm{BW}$ failed to cure mice infected with T.evansi. Conversely at a dose $1 \mathrm{mg} / \mathrm{kg} \mathrm{BW}$ given 5 days post-infection only provide temporary relief followed by relapse at all experimental animals on the eleventh day after the treatment, otherwise if treated at 8 and 11 days post-infection fails to provide relief (Jatau et al., 2010). This condition is likely due to high levels of parasitaemia so the mice die.

Generally, trypanocidal test using isometamidium chloride against T.evansi isolate from Indonesia showed the same result with Sudan isolate (Homeida et al. 1980) or Luzon and Mindanao Island isolates (Macaraeg et al. 2013) and Jatau et al. (2010). In this study did not use isometamidium chloride more than 1 $\mathrm{mg} / \mathrm{kg}$ BW according to some consideration. First, isometamidium chloride is an ethidium bromide derivate and has long withdrawal time. Secondly, there is no guarantee of cure by providing higher doses. There is obstacle in its field extrapolation due to its expensive price. One gram/sachet of trypanocidal with active ingredient of isometamidium chloride in Indonesia is IDR 250,000. Treatment at a dose of 10 $\mathrm{mg} / \mathrm{kg} \mathrm{BW}$ on large animals with a body weight about $300 \mathrm{~kg}$, needs about 3 grams per head. That means, an animal with a weight of $300 \mathrm{~kg}$ takes about 3 sachets so that the cost of drugs per head is IDR 750,000. That cost does not include other cost. It is very expensive and certainly not affordable for farmer in the most Indonesian regions. 


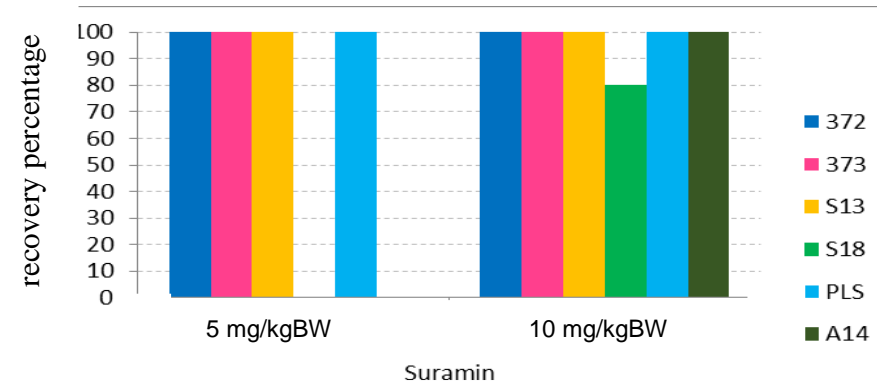

Type and dosage of trypanocidal

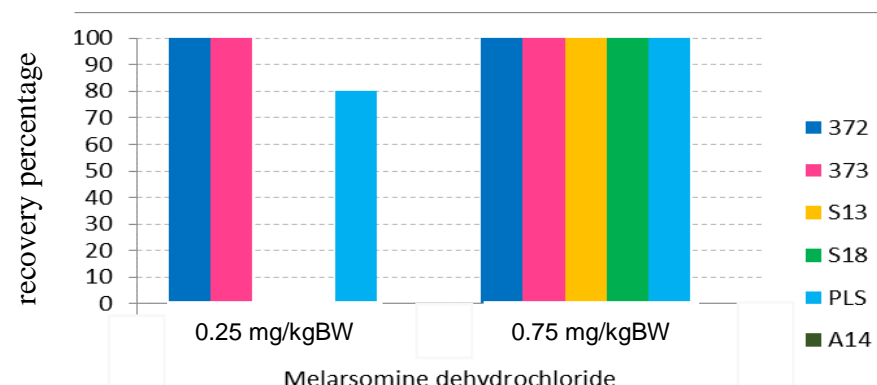

Type and dosage of trypanocidal

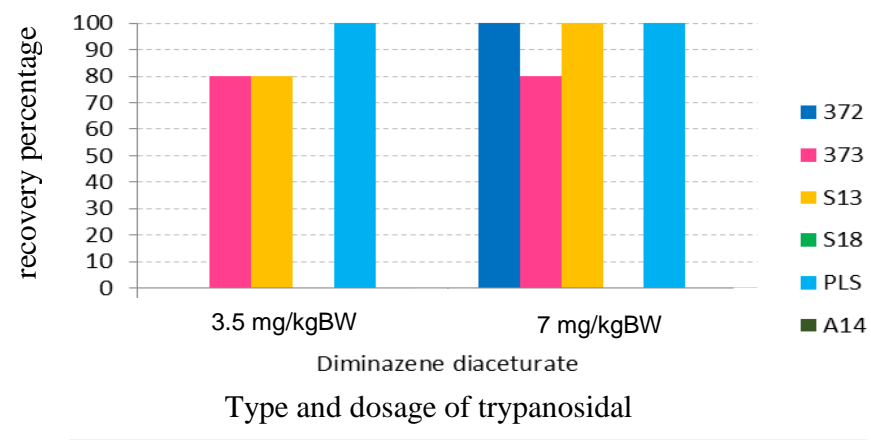

Figure 1. The recovery rate of $80 \%$ and $100 \%$ of mice infected with several isolates of T. evansi and treated by several trypanocidals (A) Melarsomine dihydrochloride; (B) Suramin; (C) Diminazene diaceturate

$372=$ T.evansi isolate from East Sumba, East Nusa Tenggara (isolated in 2012)

$373=$ T.evansi isolate from Sumba Timur, East Nusa Tenggara (isolated in 2012)

$\mathrm{S} 13=$ T.evansi isolate from Serang, Banten (isolated in 2014)

$\mathrm{S} 18=$ T.evansi isolate from Serang, Banten (isolated in 2014)

$\mathrm{PLS}=$ T.evansi isolate from Pesawaran, Lampung (isolated in 2013)

A14= T.evansi isolate from Hulu Sungai Utara, South Kalimantan (isolated in 2014) The phenomenon of relapses in trypanocidal
sensitivity test

T.evansi categorized as sensitive to trypanocidal if the infected animal were healed $100 \%$ until the end of the experiment. Therefore, trypanocidal at the dose considered to have excellent efficacy. Sometimes can occur in some animal in the experimental group that showed a relapse. Relapse is the occurrence of parasitaemia in mice that have been treated and declared cured on previous observations. The parasitaemia will remain occur until the end of the observation during the experiment or animals die after relapse. The animals were kept showed parasitaemia after treatment with trypanocidal, then the drug considered ineffective and isolates are not sensitive due to the their resistance to the drug. Resistance can occur at certain dose levels or at all dose levels.

The phenomenon of relapse may be linked to several possibilities. First, the drug levels in the blood are not sufficient to kill all parasites. Thus most of the parasites can not come into direct contact with the drug. This possibility is indicated by the presence of most of the animals who relapse within a short time and then disappear again until the end of the experiment. Elimination of parasites after relapse may be caused by 
contact with drugs that are still high levels in the blood while the parasites who relapse are very few.

The second possibility is the existence of subpopulations or clones that are resistant. Sub-population was minor population, so that the sub-population will take time to reproduce until it appears as parasitaemia. Indication of the existence of sub-populations of T.evansi in one isolate was reported by Subekti et al. (2013) and De-Menezes et al. (2004). In this type, the parasite that relapses generally will not decline again until the end of the experiment. If the therapeutic dose was increased, the parasite will disappear or remain relapse. This evidence indicates that the sub-population who relapse at higher doses is Trypanosome population that has a stronger resistance to the drug.

\section{Relapse on treatment using Melarsomine dihydrochloride}

The experimental results demonstrate that treatment with melarsomine dihydrochloride shows there are some isolates T.evansi who relapse (Figure 2A). Isolate experiencing highest relapse was A14 from Hulu Sungai Utara, South Kalimantan. In isolate A14, 80\% was relapse at dose $0.25 \mathrm{mg} / \mathrm{kg} \mathrm{BW}$ and $50 \%$ was relapse at dose $0.75 \mathrm{mg} / \mathrm{kg} \mathrm{BW}$. This result indicated that higher dose was needed for isolate A14 treatment.

Isolate S13 and S18 (from Serang, Banten) relapsed by $25 \%$ at dose $0.25 \mathrm{mg} / \mathrm{kg} \mathrm{BW}$. Similarly, isolate PLS (from Pesawaran, Lampung) relapsed by $20 \%$ at dose $0.25 \mathrm{mg} / \mathrm{kg} \mathrm{BW}$. Melarsomine dihydrochloride at a dose of $0.75 \mathrm{mg} / \mathrm{kg} \mathrm{BW}$ effective for treatment in $83.3 \%$ of T.evansi isolates that have been tested, and even provide excellent efficacy to the 372 and 373 isolates from Sumba Timur, as it only requires a dose of $0.25 \mathrm{mg} / \mathrm{kg} \mathrm{BW}$.

Relapse in treatment using melarsomine dihydrochloride was also reported by Akbar et al. (1998) in Pakistan who infected T.evansi into camel. Result showed that melarsomine dihydrochloride at dose $0.25 \mathrm{mg} / \mathrm{kg} \mathrm{BW}$ had cure rate by $66.66 \%$. However, Kabi et al. (2009) reported that there was relapse in isolate T.evansi from Uganda in treatment using melarsomine dihydrochloride at dose 0.125 $\mathrm{mg} / \mathrm{kg} \mathrm{BW}$. It also showed that $100 \%$ mice died on $18^{\text {th }}$ day infection. However, at dose 0.25 to $1 \mathrm{mg} / \mathrm{kg} \mathrm{BW}$, all of mice was cured (Kabi et al. 2009). Two isolates from Sumba Timur (isolate 372 and 373) had similar sensitivity with T.evansi isolate from Uganda used by Kabi et al. (2009) which was cure with melarsomine dihydrochloride at dose $0.25 \mathrm{mg} / \mathrm{kg} \mathrm{BW}$. The other fourth Indonesian isolates (isolate S13, S18, A14 and PLS) require melarsomine dihydrochloride with higher doses than two isolates of Uganda. This is due to recovery of $100 \%$ is only achieved when using doses $\geq 0.75 \mathrm{mg} / \mathrm{kg} \mathrm{BW}$.

\section{Relapse on treatment using Suramin}

On treatment with suramin, T.evansi isolates who relapse less than those treated using melarsomine dihydrochloride (Figure 2B). These results provide evidence that the sixth isolates of T.evansi that have been tested have better sensitivity to suramin compared to melarsomine dihydrochloride. Generally, the use of suramin at a dose $10 \mathrm{mg} / \mathrm{kg} \mathrm{BW}$ was effective for the treatment of $83.33 \%$ T.evansi isolates tested. Suramin even provides excellent efficacy in $66.67 \%$ of isolates were tested, namely 372,373, S13 and PLS as it only requires a dose of $5 \mathrm{mg} / \mathrm{kg} \mathrm{BW}$. Isolates experiencing relapse were isolate S18 and A14. Isolate A14 was $100 \%$ relapsed in treatment using suramin at dose 5 $\mathrm{mg} / \mathrm{kg} \mathrm{BW}$ but had no relapse at dose $10 \mathrm{mg} / \mathrm{kg} \mathrm{BW}$. In isolate S18, 20\% animal treated by suramin relapsed at dose $5 \mathrm{mg} / \mathrm{kg} \mathrm{BW}$ or $10 \mathrm{mg} / \mathrm{kg} \mathrm{BW}$. This indicates the possibility of resistance to suramin in these isolates.

In Indonesia, some T.evansi isolates were resistant to suramin at dose $10 \mathrm{mg} / \mathrm{kg} \mathrm{BW}$ (Payne et al. 1994). Zhou et al. (2004) also reported T.evansi isolates from China that were resistant to suramin and did not recover at a dose $10 \mathrm{mg} / \mathrm{kg} \mathrm{BW.} \mathrm{Gillingwater} \mathrm{et} \mathrm{al.} \mathrm{(2007)} \mathrm{also}$ reported that the STIB 780 and 781 isolate from Kenya were resistant to suramin. Korir et al. (2013) said that isolate EATRO 1886 from Busoga, Uganda (Trypanosoma brucei rhodesiense) also resistant to suramin at $2.5 \mathrm{mg} / \mathrm{kg}$ BW. Such evidences showed that resistance to suramin was a natural phenomenon.

\section{Relapse on treatment using Diminazene diaceturate}

Isolates who relapse after treatment using diminazene diaceturate were more higher than suramin or melarsomine dihydrochloride. At dose $3.5 \mathrm{mg} / \mathrm{kg}$ $\mathrm{BW}$, there were 5 isolates relapsed (Figure 2C). Isolate 372 and S13 relapsed by $60 \%$ and $20 \%$ respectively. Isolate A14, 373, and S18 relapsed at dose $3.5 \mathrm{mg} / \mathrm{kg}$ $\mathrm{BW}$ and $7 \mathrm{mg} / \mathrm{kg} \mathrm{BW}$. These results indicate there were sub-populations that are resistant to diminazene diaceturate in stock population of A14, 373 and S18 isolates. Therefore, diminazene diaceturate only slightly effective at a dose $7 \mathrm{mg} / \mathrm{kg}$ BW $(33.33 \%$ isolates were recovered), while at a dose of $3.5 \mathrm{mg} / \mathrm{kg}$ BW only $16.67 \%$ of isolates were recovered.

In Indonesia, diminazene diaceturate was given at a dose $3.5 \mathrm{mg} / \mathrm{kg} \mathrm{BW}$. Applications of diminazene diaceturate with a dose $3.5 \mathrm{mg} \mathrm{kg} \mathrm{BW}$ for Surra was wrong because the dose is too low despite frequent use in the field (Desquesnes et al. 2013). Although the clinical symptoms disappear but actually a small number of parasites in the blood are still alive and will multiply and cause a relapse in animals (Desquesnes et al. 2013; Gutiérrez et al. 2013). In the event of trypanosomosis caused by T.b.brucei, T.congolense and 
T.vivax, diminazene diaceturate was recommended at a dose 3.5 to $7 \mathrm{mg} / \mathrm{kg} \mathrm{BW}$ intramuscularly (Gutiérrez et al. 2013; Desquesnes et al. 2013). Conversely, in the case of surra caused by T.evansi, the recommended therapeutic dose was $7 \mathrm{mg} / \mathrm{kg}$ BW intramuscularly (Gutiérrez et al. 2013; Desquesnes et al. 2013). Therefore, in Indonesia, when diminazene aceturate applied only once treatment will lead to relapse and the case will re-emerge. However, when given twice administration making the accumulative dose being 7 $\mathrm{mg} / \mathrm{kg} \mathrm{BW}$, is expected to reduce the possibility of relapse even though most of the animals are likely to remain relapse because their resistance to diminazene diaceturate.

Akbar et al. (1998) reported that diminazene diaceturate at dose $3.5 \mathrm{mg} / \mathrm{kg} \mathrm{BW}$ cured by $66.66 \%$ of infected camels and the rest was relapse and dead. Similar with this study, mice infected with S18 isolates had relapse on $8-10^{\text {th }}$ day post-infection after being treated with diminazene diaceturate at a dose of 3.5 $\mathrm{mg} / \mathrm{kg} \mathrm{BW}$ and died at $15-16^{\text {th }}$ day post-infection. Coversely at dose $7 \mathrm{mg} / \mathrm{kg} \mathrm{BW}$, there was relapse without followed by death until the end of study. As well as in 373 isolate who showed relapse without followed by death until the end of the study. In contrast to the isolates A14 who relapse after treatment with a dose $3.5 \mathrm{mg} / \mathrm{kg} \mathrm{BW}$ and followed by death, while at a dose $7 \mathrm{mg} / \mathrm{kg} \mathrm{BW}, 20 \%$ relapse and die and the rest $(80 \%)$ only relapse.

Mohammed (2008) has also been infecting T.evansi isolates from Saudi Arabia in Swiss-Webster mice and treated with diminazene diaceturate at a dose $3.5 \mathrm{mg} / \mathrm{kg}$ BW. The experimental results showed that $60 \%$ of mice cured while the rest were died without relapse. These results also indicate that the isolates from Saudi Arabia had a sub-population were resistant to diminazene diaceturate. Therefore, $40 \%$ of the infected animal does not occur parasitaemia reduction and resulting in death. Qadeer et al. (2015) reported that the goats were infected with T.evansi and treated with diminazene diaceturate at a dose 3.5 and $7 \mathrm{mg} / \mathrm{kg} \mathrm{BW}$ have relapse $(100 \%)$, while the recovery without relapse only occurred at a doses $10.5 \mathrm{mg} / \mathrm{kg} \mathrm{BW}$.

Kabi et al. (2009) reported that Swiss Webster mice that have been infected with T.evansi isolates from Uganda and treated with diminazene diaceturate (dose 1.75 to $14 \mathrm{mg} / \mathrm{kg}$ ) were all dead on $18^{\text {th }}$ day postinfection. These results correspond with the results of Zhang et al that proves the failure of diminazene diaceturate to kill T.evansi isolate from China, the Philippines and Ethiopia, both in vitro and in vivo (Kabi et al. 2009). These results indicate that the T.evansi isolates from Uganda used by Kabi et al. (2009) had higher resistance than Saudi Arabia isolate used by
Mohammed (2008), Pakistan isolate used by Akbar et al. (1998), and six isolates from Indonesia were used in this study.

Macaraeg et al. (2013) also have infected mice with T.evansi isolates of the island of Luzon, Visayas and Mindanao. Luzon isolates require diminazene diaceturate with a therapeutic dose of $5 \mathrm{mg} / \mathrm{kg} \mathrm{BW}$ to cure mice $(100 \%)$ and failed to cure at lower doses. Visayas isolate require diminazene diaceturate at a dose $10 \mathrm{mg} / \mathrm{kg} \mathrm{BW}$ to achieve $100 \%$ recovery, while at doses of 5,3 and $1 \mathrm{mg} / \mathrm{kg} \mathrm{BW}$ the recovery rates were $80 \%$, $60 \%$ and $0 \%$ respectively. Diminazene diaceturate at a dose $3 \mathrm{mg} / \mathrm{kg}$ was able to cure $(100 \%)$ mice infected with Mindanao isolates, while at a dose $1 \mathrm{mg} / \mathrm{kg} \mathrm{BW}$ only cured $20 \%$ experimental animal. However, in experiments conducted by Macaraeg et al. (2013) does not provide information whether there is any incidence of relapse.

The results showed that isolate $T$. evansi from different island in Philippine had different sensitivity associated with therapeutic doses are used. T. evansi isolates from Luzon and Mindanano were sensitive to diminazene diaceturate at dose 5 and $3 \mathrm{mg} / \mathrm{kg} \mathrm{BW}$ respectively. Visayas isolate require dose above 7 $\mathrm{mg} / \mathrm{kg}$ BW. The similar result was obtained in experiments using six isolates from Indonesia. Isolates 372 and S13 only recovered $100 \%$ when using diminazene diaceturate at a dose $7 \mathrm{mg} / \mathrm{kg}$ BW. However, four other isolates remained unrecovered at a dose of $7 \mathrm{mg} / \mathrm{kg} \mathrm{BW}$ and even the S18 and A14 isolates showed relapses $(100 \%)$.

\section{Determination of effective Trypanocidal for Surra Disease in Indonesia}

Based on these results, it was difficult to determine the most appropriate trypanocidal used for the treatment of Surra in all regions of Indonesia. This is due to the diversity of the effectiveness of some trypanocidals on different T.evansi isolates. Evidence from this study indicates that each isolate has a different sensitivity to the diverse trypanocidal. Those differences require interpretation which leads to a specific location for the use of trypanocidal (Table 2). T.evansi originating from different areas will give different responses to the type and dosage of trypanosidal being used. Example from this study, the effective trypanocidal against A14 isolate is suramin at a dose $10 \mathrm{mg} / \mathrm{kg} \mathrm{BW}$. Instead, the most effective trypanocidal against 372 and 374 isolates are melarsomine dihydrochloride at a dose 0.25 to 0.75 $\mathrm{mg} / \mathrm{kg} \mathrm{BW}$, suramin at a dose 5 to $10 \mathrm{mg} / \mathrm{kg} \mathrm{BW}$ and diminazene diaceturate at $7 \mathrm{mg} / \mathrm{kg} \mathrm{BW}$. Similar conditions also apply to isolates from other areas also demonstrates different sensitivities. 


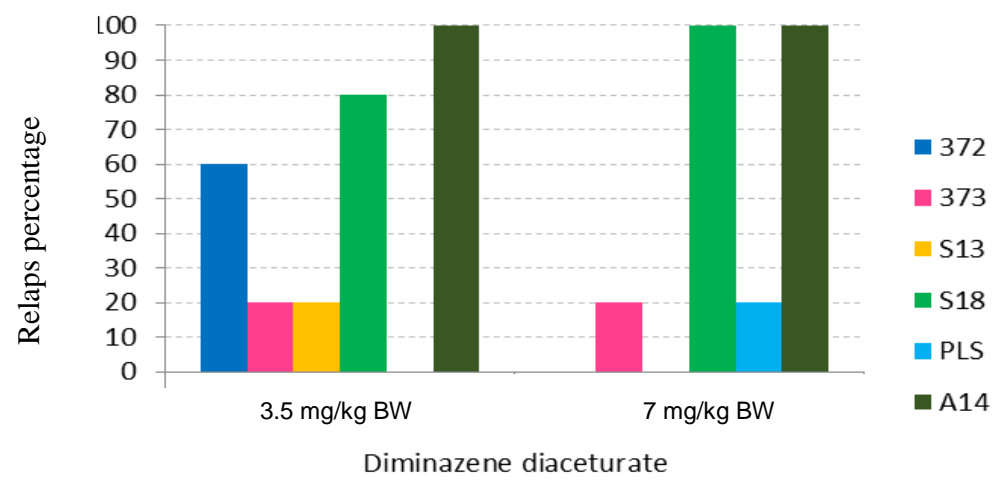

Type and dosage of trypanocidal

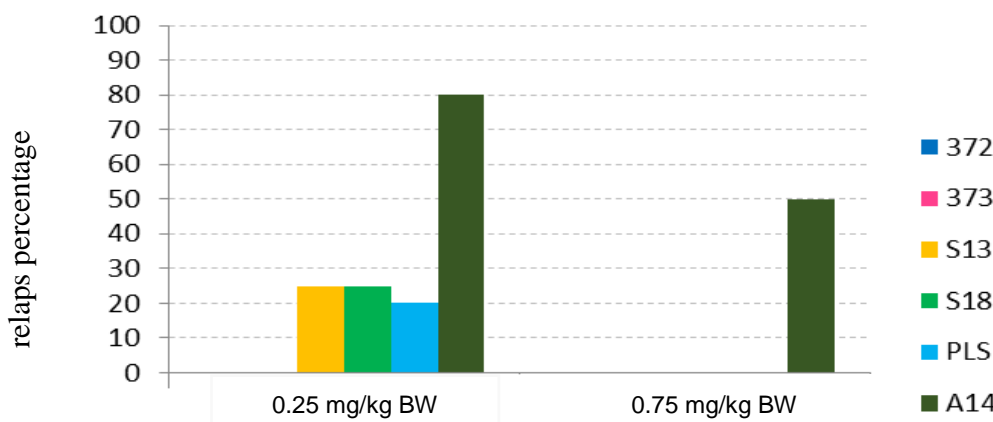

Melarsomine dehydrochloride

Type and dosage of trypanocidal

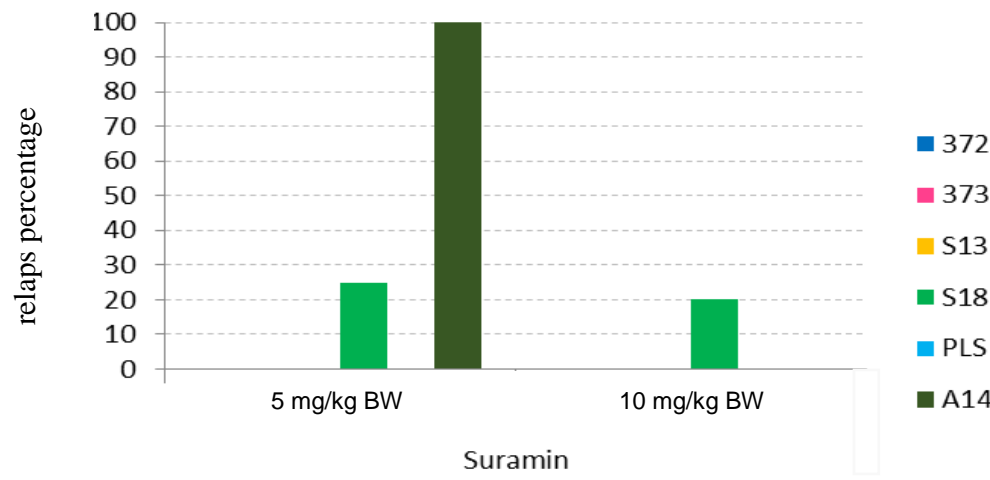

Type and dosage of trypanocidal

Figure 2. Percentage of relapse in treated mice by several trypanocidal. (A) Melarsomine dihydrochloride; (B) Suramin; (C) Diminazene diaceturate

$372=$ T.evansi isolate from Sumba Timur, East Nusa Tenggara (isolated in 2012)

$373=$ T. evansi isolate from Sumba Timur, East Nusa Tenggara (isolated in 2012)

$\mathrm{S} 13=$ T.evansi isolate from Serang, Banten (isolated in 2014)

$\mathrm{S} 18=$ T.evansi isolate from Serang, Banten (isolated in 2014)

$\mathrm{PLS}=$ T.evansi isolate from Pesawaran, Lampung (isolated in 2013)

A14= T.evansi isolate from Hulu Sungai Utara, South Kalimantan (isolated in 2014) 
Subekti et al

pagated in mice

Table 2. Summary of the most suitable selected trypanocidal against T. evansi isolate from infected area in Indonesia

\begin{tabular}{|c|c|c|c|}
\hline \multirow{2}{*}{ Isolate } & \multicolumn{3}{|c|}{ Effective drug as Trypanocidal } \\
\hline & The Drugs of Choice & The 2nd Choice & Not Recommended \\
\hline 372 & Melarsomine dihydrochloride, Suramin & Diminazene diaceturate $7 \mathrm{mg} / \mathrm{kg} \mathrm{BW}(100 \%)$ & Isometamidium chloride \\
\hline S13 & - & Melarsomine dihydrochloride, Suramin, Diminazene diaceturate & Isometamidium chloride \\
\hline S18 & - & Melarsomine dihydrochloride, Suramin & Diminazene diaceturate, Isometamidium chloride \\
\hline A14 & - & Suramin $10 \mathrm{mg} / \mathrm{kg} \mathrm{BW}$ & $\begin{array}{l}\text { Suramin } 5 \mathrm{mg} / \mathrm{kg} \mathrm{BW} \text {, Melarsomine dihydrochloride, } \\
\text { Diminazene diaceturate, Isometamidium chloride }\end{array}$ \\
\hline PLS & Suramin & $\begin{array}{l}\text { Melarsomine dihydrochloride (80-100\%), Diminazene } \\
\text { diaceturate }(80-100 \%)\end{array}$ & Isometamidium chloride \\
\hline
\end{tabular}

Table 3. Summary of trypanocidal efficacy criteria against T. evansi isolate from infected area in Indonesia

\begin{tabular}{|c|c|c|c|c|c|c|c|}
\hline Trypanocidal & Dose & 372 & 373 & S13 & S18 & A14 & PLS \\
\hline \multirow{2}{*}{$\begin{array}{l}\text { Melarsomine } \\
\text { dihydrochloride }\end{array}$} & $0.25 \mathrm{mg} / \mathrm{kg} \mathrm{BW}$ & Effective & Effective & Ineffective & Effective & Ineffective & Effective \\
\hline & $0.75 \mathrm{mg} / \mathrm{kg} \mathrm{BW}$ & Effective & Effective & Effective & Effective & Ineffective & Effective \\
\hline Suramin & $10 \mathrm{mg} / \mathrm{kg} \mathrm{BW}$ & Effective & Effective & Effective & Effective & Effective & Effective \\
\hline \multirow{2}{*}{ Diminazene diaceturate } & $3.5 \mathrm{mg} / \mathrm{kg} \mathrm{BW}$ & Ineffective & Effective & Effective & Ineffective & NA & Effective \\
\hline & $7 \mathrm{mg} / \mathrm{kg} \mathrm{BW}$ & Effective & Effective & Effective & Ineffective & Ineffective & Effective \\
\hline \multirow{2}{*}{ Isometamidium chloride } & $0.5 \mathrm{mg} / \mathrm{kg} \mathrm{BW}$ & Ineffective & Ineffective & Ineffective & Ineffective & Ineffective & Ineffective \\
\hline & $1 \mathrm{mg} / \mathrm{kg} \mathrm{BW}$ & Ineffective & Ineffective & Ineffective & Ineffective & Ineffective & Ineffective \\
\hline
\end{tabular}

$\mathrm{NA}=$ not analyzed, it was not analyzed due to the number of live animal was less than 3 heads 
The results of this study indicate that the use of trypanocidal will be divided into three conditions. The first condition is a drug that was not be recommended due to ineffective for infected experimental animals. The second condition is a drug which was only effective in large doses and in effective in small doses. This kind of trypanocidal may still be used regularly followed by an increase in dose and must be accompanied by supervision of the possibility of intoxication. The last condition is drug which was effective used at small doses. Trypanocidal in this category was recommended as the drug of choice for treatment that can be applied effectively.

Nevertheless, drug categories above are only suitable for the treatment of cases of Surra on individual animals and specific locations at the field level. Conversely, when directed as a reference for national policies for the procurement of drugs with the aim of subsidizing procurement of drugs for for a variety of cases in various regions in Indonesia would lead to difficulties in setting priorities for procurement. Therefore, it needs to set priorities by considering the cumulative effectiveness based on the results of the drug test.

Eisler et al. (2001) suggest that a trypanocidal declared effective if the experiment proved $\geq 80 \%$ of experimental animals have been recovered. Referring to this provision, it can be arranged a general idea of the effectiveness of some trypanocidal against T.evansi isolates from Indonesia that have been tested. Generally, if using criteria of Eisler et al. (2001), suramin was effective on all isolates, except on A14 isolate which needed $10 \mathrm{mg} / \mathrm{kg}$ BW (Table 3). Melarsomine dihydrochloride at dose $0.75 \mathrm{mg} / \mathrm{kg} \mathrm{BW}$ was effective on 5 isolates (83.33\%), except on A14 isolate. Melarsomine dihydrochloride at a dose 0.25 $\mathrm{mg} / \mathrm{kg} \mathrm{BW}$ was only effective on 4 isolates $(66.7 \%)$, except for S13 and A14. Diminazene diaceturate declared effective on 4 of 6 isolates $(66.67 \%)$ were tested when used at dose $7 \mathrm{mg} / \mathrm{kg}$ BW and only effective in 3 of 5 isolates $(60 \%)$ when used at dose 3.5 $\mathrm{mg} / \mathrm{kg} \mathrm{BW}$. Isometamidium chloride was known as a drug that is not effective in all isolates from Indonesia so it is not recommended for use. Therefore, based on these results was known that in general, the order of priority of procurement trypanocidal is suramin and melarsomine dihydrochloride followed by diminazene diaceturate as the last option.

\section{CONCLUSION}

Every isolates have different sensitivities to trypanosidal, hence the use of trypanocidal tend to be specific locations. In general, suramin and melarsomine dihydrochloride is most effective for some T.evansi isolates from Indonesia. The isometamidium chloride was not recommended to use for the treatment of Surra in Indonesia.

\section{ACKNOWLEDGEMENT}

Authors were grateful to M. Dahlan and Suharyatna for helps during this research. This research was funded by DIPA of Indonesian Research Center for Veterinary Science, Bogor in 2014.

\section{REFERENCES}

Abdelrahman SH. 2011. Trypanocidal activities of some Sudanese medicinal plants against experimental Trypanosoma evansi infection. Res J Med Plant. p. 1-8.

Akbar SJ, Munawar G, Ul-Haq A, Khan SM, Khan MA. 1998. Efficacy of trypanocidal drugs on experimentally induced trypanosomiasis in racing camel. J Protozool Res. 8:249-252.

Aman MMM. 2013. Effect of propolis extracts on trypanosoma evansi in rats. Glob J Plant Ecophysiol. $3: 18-20$

De-Menezes VT, Queiroz AO, Gomes MAM, Marques MAP, Jansen AM. 2004. Trypanosoma evansi in inbred and Swiss-Webster mice: Distinct aspects of pathogenesis. Parasitol Res. 94:193-200.

Desquesnes M, Dargantes A, Lai DH, Lun ZR, Holzmuller P and Jittapalapong S. 2013. Trypanosoma evansi and Surra: A Review and Perspectives on Transmission, Epidemiology and Control, Impact, and Zoonotic Aspects. BioMed Research International. 321237, 20 pages doi: 10.1155/2013/321237.

[Dirkeswan] Direktorat Kesehatan Hewan. 2012. Pedoman pengendalian dan pemberantasan penyakit Trypanosomiasis (Surra). Jakarta (Indonesia): Direktorat Kesehatan Hewan, Direktorat Jenderal Peternakan dan Kesehatan Hewan, Kementerian Pertanian.

Dorneles FS, Da Silva AS, Oliveira CB, Zimmermann CEP, Rosa LD, Tonin AA, De Oliveira ECP, Santurio JM, Monteiro SG. 2013. Susceptibility of Trypanosoma evansi in the Copaiba Oil: In Vitro test and in mice experimentally infected with the Parasite. Acta Sci Vet. 41:1-6.

Eisler MC, Brandt J, Bauer B, Clausen PH, Delespaux V, Holmes PH, Ilemobade A, Machila N, Mbwambo H, McDermott J, Mehlitz D, Murilla G, Ndung'u JM, Peregrine AS, Sidibé I, Sinyangwe L, Geerts S. 2001. Standardised tests in mice and cattle for the detection of drug resistance in tsetse-transmitted trypanosomes of African domestic cattle. Vet Parasitol. 97:171-183.

Gillingwater K, Büscher P, Brun R. 2007. Establishment of a panel of reference Trypanosoma evansi and Trypanosoma equiperdum strains for drug screening. Vet Parasitol. 148:114-121. 
Gutiérrez C, González-Martín M, Corbera JA, Junco MTT. 2013. Chemotherapeutic agents against pathogenic animal trypanosomes. In Microbial pathogens and strategies for combating them: science, technology and education. Méndez-Vilas A, editor. Spain: Formatex Research Center. p. 1564-1573.

Homeida AM, El Amin EA, Adam SEI, Mahmoud MM 1980. The Effect of Samorin (Isometamedium chloride) on Trypanosoma evansi infection in mice. $\mathrm{Br} \mathrm{J}$ exp Pathol. 61:380-389.

Jatau ID, Lawal AI, Agbede RIS, Abdurrahman EM. 2010 Efficacies of diminazene aceturate and isometamidium chloride In Trypanosoma evansi experimentally infected rats. Sokoto J Vet Sci. 8:4-8.

Kabi F, Waiswa C, Olaho-Mukani W, Walubengo J. 2009. Comparative in vivo drug sensitivity study of Trypanosoma evansi isolates from Moroto, Uganda to Trypan ${ }^{\circledR}$, Triquin- $\mathrm{S}^{\circledR}$ and Cymelarsan ${ }^{\circledR}$. Afr J Anim Biomed Sci. 4:36-42.

Korir SC, Mburu J, Shivairo R, Serem E, Arasa G, Cheruiyot JC, Chome J, Mdachi E. 2013. Comparison of drug Sensitivity and Pathogenicity of Trypanosoma brucei rhodesiense isolates with their respective clones originating from Busia and Busoga. J Nat Sci Res. 3:141-149.

Macaraeg BB, Lazaro JV, Abes NS, Mingala CN. 2013. Invivo assessment of the effects of trypanocidal drugs against Trypanosoma evansi isolates from Philippine water buffaloes (Bubalus bubalis). Veterinarski Arhiv. 83:381-392.

Melaku A, Birasa B. 2013. Drugs and drug resistance in African animal trypanosomosis: A Review. Eur J Appl Sci. 5:84-91.

Mohammed HI. 2008. Comparative in vivo activities of diminazene, suramine, quinapyramine and homidium bromide on Trypanosoma evansi infection in mice. Scientific J King Faisal University (Basic and Applied Sciences). 9:139-147.
Nzelibe HC, Habila N, Agbaji AS. 2013. Synergy of Azadirachta indica seed and Tridax procumbens leaf extracts induced death of Trypanosoma evansi. Int J Trad Nat Med. 3:11-18.

[OIE] Office International des Epizooties. 2012. Trypanosoma evansi Infection (Surra). OIE Terrestrial Manual 2012, Chapter 2.1.17. Paris (France): Office International des Epizooties. p. 1-15.

Payne RC, Sukanto IP, Partoutomo S, Jones TW. 1994. Efficacy of Cymelarsan treatment of suramin resistant Trypanosoma evansi in cattle. Trop Anim Health Prod. 26:92-94.

Qadeer MA, Adamu T, Gumel MA, Nganjiwa JI. 2015. Sensitivity of bovine Trypanosoma vivax isolate using three trypanocidal drugs in experimentally induced caprine trypanosomosis. Int J Sci Res. 4:2343-2352.

Sones KR, Njogu AR, Holmes PH. 1998. Assessment of sensitivity of Trypanosoma congolense to isometamidium chloride: a comparison of tests using cattle and mice. Acta Tropica. 45:153-164.

Subekti DT, Sawitri DH, Wardhana AH, Suhardono. 2013. Pola parasitemia dan kematian mencit yang diinfeksi T. evansi Indonesia. JITV. 18:274-290.

Subekti DT. 2014. Perkembangan, struktur, mekanisme kerja dan efikasi trypanosidal untuk Surra. Wartazoa. 24:115 .

Steverding D. 2010. The development of drugs for treatment of sleeping sickness: A historical review. Parasites Vectors. 3:1-9.

Uilenberg, G. 1998. A Field Guide for the Diagnosis, Treatment and Prevention of African Animal Trypanosomosis. FAO Corporate Document Repository. Rome (Italy): Food and Agriculture Organization of the United Nations.

Zhou J, Shen J, Liao D, Zhou Y, Lin J. 2004. Resistance to drug by different isolates Trypanosoma evansi in China. Acta Tropica. 90:271-275. 